\title{
COCONUT GENETIC RESOURCES
}

\author{
by \\ Dr. M. K. NAIR ${ }^{1}$
}

\section{Origin of Coconut}

It is presurned that the generic name, Cocos as well as the popular name coconut are derived from the spanish word 'coco' meaning 'monkey face' probably a reference to the three sears on the base of the shell resembling a monkey's face (Rosengarten, 1984). The origin of coconut was placed by Martius (1850) on the West Coast of Central America near the Isthmus of Panama. On the basis of evidences for the cultivation of coconut in Sri Lanka by about 300 BC. as well as the discovery of a fossil (Pliocene) Cocos in Newzealand (Hill, 1929) and in the deserts of Rajasthan (Kaul, 1951) the theory of Central American origin has been contested. Early spanish explorers discovered the cultivation of coconut on the Pacific.Coast of Panama in pre-Columbian times. The first report of appearance of coconut in Western Mexico came around 1540 AD and it is believed to have spread to Mexico in the last decade of the $16^{\text {th }}$ century (Bruman, 1945). It is presurned that coconut might have been carried to Mexico by ocean currents from Polynesia before the discovery of the New World (Purseglove, 1972). The available evidences point to the domestication of coconut in the Indo-Pacific area (de Candolle, 1886; Beccari, 1917; Vavilov, 1951; Corner, 1966; Child, 1974). According to the most widely accepted theory, the origin of coconut is in the Old World, somewhere in Southeast Asia or the Pacific Islands from where it might have been transported to other regions either by man or by sea currents. Evidences are available in literature regarding the germination capacity of coconut even after floating in the sea for a period of 110 days and within this period it is capable of travelling up to 4,900 kilometers (Edmondson, 1941). It indicates the possibility of natural dissernination between the islands in the Pacific and Indian Oceans (Harries, 1978).

\section{Genetic Variability and Varieties}

Tall and dwarf are the two distinct varieties of coconut. The tall palms, sometimes referred as var. typica Nar., are the most commonly cultivated in all the coconut growing areas the world. Tall palms generally grow to a height of 25-30 m and have a comparatively long pre-bearing age of 6-10 years. They are normally cross-pollinated as there is usually no overlapping of male and female phases. Fruit is generally medium to large in size and the nuts mature within a period of 12 months. West Coast Tall, Lakshadweep Ordinary, East Coast Tali and Andaman Ordinary are some of the distinct tall types present in India.

Dwarf palms, sometimes referred to as var. nany (Griff.) Nar., are characterised by their short stature. They are quicker to come to bearing (3-4 years), are easier to harvest and are short-lived. They have thin trunks without a swollen base or 'bole' and the fully cleveloped fronds rarely exceed 4 m. Though the dwarf palms yield heavily, they have a tendency to irregular bearing. Dwarfs are identified mainly by the colour of their nuts. They are presurned to have originated from tall palms either through mutation (Menon and Pandalai, 1958) or by inbreeding in talls (Swarninathan and Nambiar, 1961). In India, two important dwarf types found are Chowghat Green Dwarf and Chowghat Orange Dwarf mainly clescribed by the colour of their ituts and petiole. In the case of talls, the copra content is usually over $150 \mathrm{~g} / \mathrm{nut}$, while in dwarfs it ranges from $90 \mathrm{~g}$ to $120 \mathrm{~g} / \mathrm{nut}$. The oii percentage, varies from 66-70 in talls and is about 65 in dwarfs.

In India, in addition to these two groups, there are few other distinct type such as Lakshadweep Micro, Kappadam, Andaman Giant, Calangute, Nadora and Benaulim which are talls, and Gangabondam a dwarf from Andhra Pradesh. Ramachandran et al. (1977) reported Ayiramkachi

\footnotetext{
${ }^{1}$ Director, Central Plantation Crops Research Institute Kasaragod - 671 124, Kerala.
} 
an intermediate type between tall and dwarf in Tamil Nadu. Different tall and dwarf cultivars have also been identified from Orissa (Panda, 1982).

\section{Collection and Conservation}

Systernatic research on crop improvement programme in coconut was perhaps started first in India in 1916. The earliest exotic introductions into India were in 1924 from the Philippines, Malaysia, Fiji, Indonesia, Sri Lanka and Vietnam which formed the nucleus population for many of the research programmes. The germplasm exchange programme was further intensified in 1952 and in 1958 surveys for collection of indigenous germplasm was started.

At present, the Central Plantation Crops Research Institute, Kasaragod is maintaining the World's largest assemblege of germplasm of 40 indigenous and 86 exotic cultivars. The exotic collections from 22 countries of South and South East Asia, Caribbean Islands, Indian Ocean Islands, Pacific Ocean Islands and African countries comprise of 72 talls, 12 dwarfs, one semi tall and one hybrid (Table 1-A). These include the collection made by a tearn of two scientists from CPCRI based on a survey in seven Pacific Ocean Territories cluring 1981. The purpose of the survey was to collect and conserve coconut germplasm with a view to screening for their reaction to root (wilt) disease prevalent in 8 southern districts of Kerala. The collections were made using the descriptor approved by the IBPGR (1978) and all the tall cultivars were sampled randomly and the dwarf cultivars sampled on a biased basis due to the low frequency of their occurrence. A total of 24 collections were made which included 21 tall and 3 dwarf types. Tllese collections included the well-known cultivars such as Rennel Tall, Solomon Tall, Fiji Tall, Samoan Tall, Tahiti Tall, Rangiroa Tall and Dwarf Yellow (American Samoa), Dwarf Orange (Rangiroa) and Niuleka Dwarf (Fiji). nese collections were planted at the CPCRI World Coconut Germplasm Centre, Sipighat, Andamans for quarantine consideration (Rao and Koshy, 1982). The indigenous collections from Kerala, Tamil Nadu, Karnataka, Andhra Pradesh, Gujarat, Orissa, Andaman \& Nicobar Islands, and Laccadive Islands comprise of 29 talls and 11 dwarfs (Table 1B).

Table 1A COCONUT GERMPLASM ACCESSIONS AT CPCRI (Kasaragod and Sipighat)

A. Exotic accessions.

\begin{tabular}{|c|c|c|c|c|c|}
\hline \multirow{2}{*}{ Source of collection } & \multirow{2}{*}{$\begin{array}{c}\text { No. of } \\
\text { accessions }\end{array}$} & \multirow{2}{*}{$\begin{array}{l}\text { SI. } \\
\text { No. }\end{array}$} & \multirow{2}{*}{ Name of cultivar } & \multicolumn{2}{|c|}{ No. of palms } \\
\hline & & & & Talls & Drawfs \\
\hline 1 & 2 & 3 & 4 & 5 & 6 \\
\hline \multicolumn{6}{|l|}{ SOUTH EAST ASIA } \\
\hline I. Borneo & 3 & 1 & Borneo & 20 & - \\
\hline & & 2 & Kongthienyong & 8 & - \\
\hline & & 3 & Standard Kudat & 13 & - \\
\hline II. Indonesia & 1 & 4 & Java & 24 & - \\
\hline III. Malaysia & 8 & 5 & Malayan Orange Dwarf & - & 26 \\
\hline & & 6 & Malayan Yellow Dwarf & - & 40 \\
\hline & & 7 & Malayan Green Dwarf* & - & 37 \\
\hline & & 8 & Malayan Tall & 2 & - \\
\hline & & 9 & F S M & 22 & - \\
\hline & & 10 & Klapawangi & 9 & - \\
\hline & & 11 & S.S. Green & 30 & - \\
\hline & & 12 & S.S. Apricot & 14 & - \\
\hline IV. Philippines & 7 & 13 & Phil. Ordinary & 28 & - \\
\hline & & 14 & Phil. Laguna & 6 & - \\
\hline
\end{tabular}




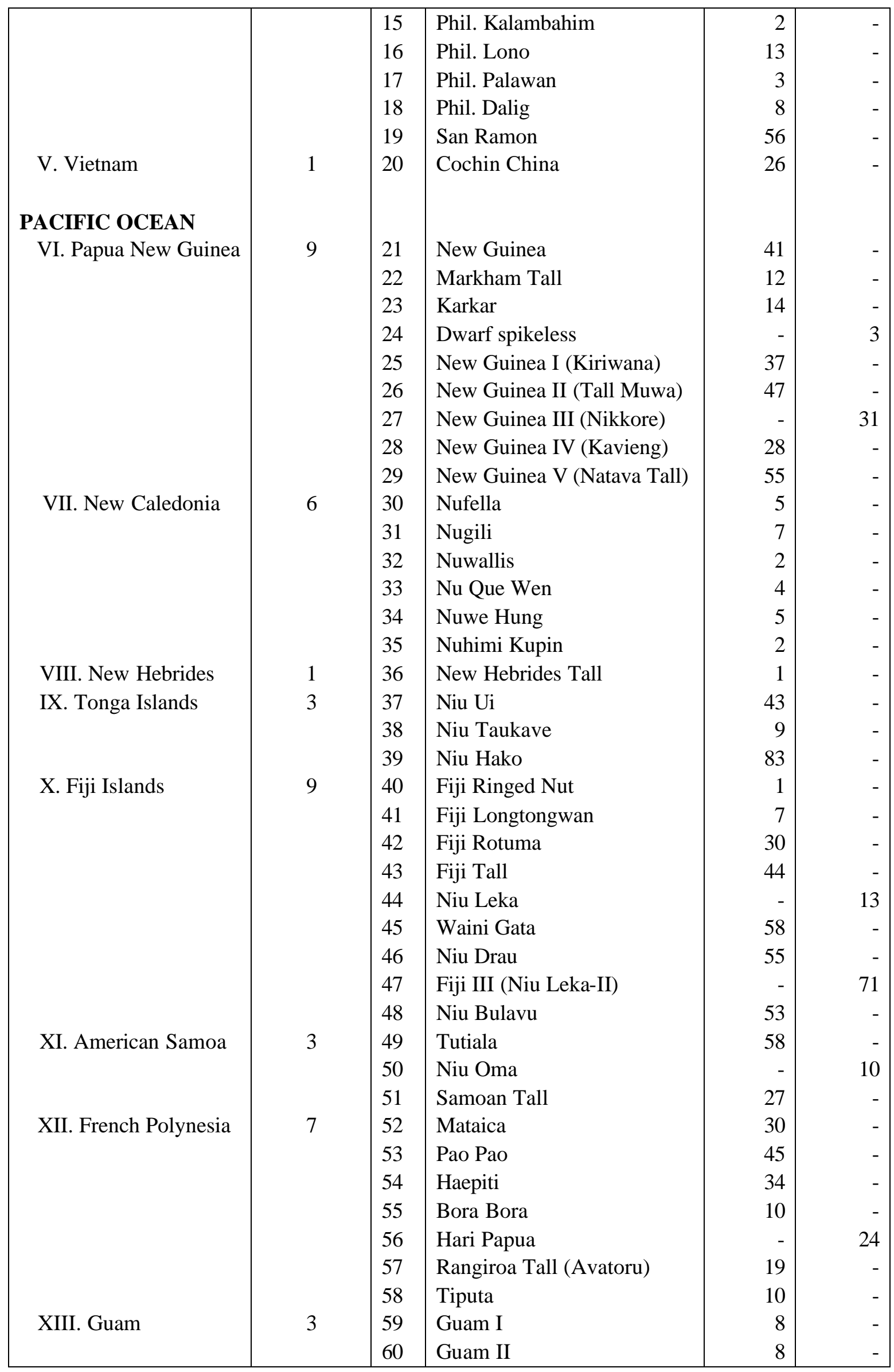




\begin{tabular}{|c|c|c|c|c|c|}
\hline & & 61 & Guam III & 3 & - \\
\hline XIV. Lifou & 1 & 62 & Lifou Tall & 10 & - \\
\hline \multirow[t]{3}{*}{ XV. Solomon Islands } & 3 & 63 & B.S.I. & 13 & - \\
\hline & & 64 & Solomon Tall & 3 & - \\
\hline & & 65 & Rennel Tall & 2 & - \\
\hline \multicolumn{6}{|c|}{ CENTRAL AMERICA, SOUTH AMERICA AND ATLANTIC REGION } \\
\hline \multirow[t]{2}{*}{ XVI. Surinam } & 2 & 66 & Surinam Tall & 7 & - \\
\hline & & 67 & Surinam Dwarf & - & 5 \\
\hline \multirow[t]{2}{*}{ XVII. Jamaica } & 2 & 68 & Jamaica Tall & 8 & - \\
\hline & & 69 & Jamaica Sanblas & 28 & - \\
\hline \multirow[t]{2}{*}{ XVIII. Trinidad } & 2 & 70 & St. Vincent & 16 & - \\
\hline & & 71 & Blanchissuse & 11 & - \\
\hline XIX. Panama & 1 & 72 & Panama Tall & 5 & - \\
\hline \multicolumn{6}{|l|}{ AFRICAN REGION } \\
\hline \multirow[t]{2}{*}{ XX. Nigeria } & 2 & 73 & Nigerian Tall & 6 & - \\
\hline & & 74 & Nigerian Dwarf & - & 6 \\
\hline XXI. Kenya & 1 & 75 & Kenya Tall & 22 & - \\
\hline \multirow[t]{3}{*}{ XXII. Ivory Coast } & 3 & 76 & Camaroon Dwarf & - & 11 \\
\hline & & 77 & West African Tall & 19 & - \\
\hline & & 78 & Mawa (PB 121)** & 25 & - \\
\hline XXIII. Zanzibar & 1 & 79 & Zanzibar Tall & 15 & - \\
\hline \multicolumn{6}{|l|}{ INDIAN OCEAN } \\
\hline \multirow[t]{6}{*}{ XXIV. SriLanka } & 6 & 80 & Ceylon Tall & 11 & - \\
\hline & & 81 & Gonthembili & 7 & - \\
\hline & & 82 & King Coconut & - & 14 \\
\hline & & 83 & Ceylon Yellow Dwarf & - & 1 \\
\hline & & 84 & Ceylon Green Dwarf & - & 2 \\
\hline & & 85 & Ceylon Orange Dwarf & - & 1 \\
\hline \multirow[t]{7}{*}{ XXV. Seychelles } & 1 & 86 & Seychelles & 7 & \\
\hline & & & Talls & 68 & \\
\hline & & & Semitall & - & 1 \\
\hline & & & Dwarfs & - & 16 \\
\hline & & & Hybrid & 1 & - \\
\hline & & & & 69 & 17 \\
\hline & & & TOTAL & 86 & \\
\hline
\end{tabular}

* Semi Tall **Hybrid 
Table IB. Indigenous accessions.

\begin{tabular}{|c|c|c|c|c|c|}
\hline 1 & 2 & 3 & 4 & 5 & 6 \\
\hline \multirow{6}{*}{ Kerala } & 6 & 1 & Chowghat Orange Dwarf & - & 84 \\
\hline & & 2 & Chowghat Green Dwarf & - & 36 \\
\hline & & 3 & Kaithathali & 1 & - \\
\hline & & 4 & Kappadam & 14 & - \\
\hline & & 5 & Spicata & 19 & - \\
\hline & & 6 & West Coast Tall & 77 & - \\
\hline \multirow[t]{8}{*}{ Tamil Nadu } & 8 & 7 & Adirampatnam & 1 & - \\
\hline & & 8 & Ayiramkachi & 18 & . \\
\hline & & 9 & Kulasekharam Green Dwarf & - & 55 \\
\hline & & 10 & Kulasekharam Orange Dwarf & - & 30 \\
\hline & & 11 & Kulasekharam Yellow Dwarf & - & 50 \\
\hline & & 12 & Pattukottai Green Dwarf & - & 4 \\
\hline & & 13 & Pattukottai Red Dwarf & - & 1 \\
\hline & & 14 & East Coast Tall & 35 & - \\
\hline \multirow[t]{2}{*}{ Karnataka } & 2 & 15 & Kenthali & - & 4 \\
\hline & & 16 & Tiptur Tall I & 4 & - \\
\hline \multirow[t]{5}{*}{ Andhra Pradesh } & 5 & 17 & Gangabondam & - & 44 \\
\hline & & 18 & Gangabhavani & 2 & - \\
\hline & & 19 & Gangapani & 5 & - \\
\hline & & 20 & Rangoon Kobbari & 9 & - \\
\hline & & 21 & Verrikobbari & 4 & - \\
\hline \multirow[t]{3}{*}{ Goa } & 3 & 22 & Benaulim & 13 & - \\
\hline & & 23 & Calangute & 10 & - \\
\hline & & 24 & Nadora & 11 & - \\
\hline Gujarat & 1 & 25 & Gujarat Zanzibar & 9 & - \\
\hline Orissa & 1 & 26 & Sakhi Gopal & 7 & - \\
\hline \multirow[t]{11}{*}{ Andamans } & 11 & 27 & Andaman Ordinary & 34 & - \\
\hline & & 28 & Andaman Giant & 25 & $\begin{array}{lll}- & - \\
-1\end{array}$ \\
\hline & & 29 & Andamzo Ranguchan & 19 & - \\
\hline & & 30 & Andaman Dwarf & - & 5 \\
\hline & & 31 & Carnicobar & 58 & - \\
\hline & & 32 & Auck Chung & 36 & - \\
\hline & & 33 & Tamaloo & 36 & - \\
\hline & & 34 & Kimos & 36 & - \\
\hline & & 35 & Kimmai & 36 & 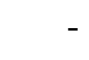 \\
\hline & & 36 & Katchal & 35 & - \\
\hline & & 37 & Campbell Bay & 34 & - \\
\hline
\end{tabular}




\begin{tabular}{|l|r|r|l|r|r|}
\hline Lakshadweep & 3 & 38 & Laccadive Ordinary & 76 & - \\
& & 39 & Laccadive Vicro & 37 & - \\
& 40 & Laccadive Orange Dwarf & - & 2 \\
& & & Talls & 29 & - \\
& & & Dwarfs & - & 11 \\
& & & Total & $\mathbf{4 0}$ & \\
\hline
\end{tabular}

Germplasm collections are also being maintained at twdlve centres under the All India Co-ordinated Research Projects on Palms (Table 2).

Table 2 Coconut germplasm available in the Co-ordinating Centres

\begin{tabular}{|r|l|r|r|r|}
\hline S.No. & \multicolumn{1}{|c|}{ Centres } & Exotic & Indigenous & Total \\
\hline 1. & Aliyarnagar & 13 & 6 & 19 \\
2. & Ambajipet & 6 & 5 & 11 \\
3. & Arsikere & 11 & 2 & 13 \\
4. & Andamans & - & 8 & 8 \\
5. & Coimbatore & 2 & 5 & 7 \\
6. & Jagadalpur & 11 & 5 & 16 \\
7. & Jalalgarh & 11 & 2 & 16 \\
8. & Konark & 11 & 1 & 13 \\
9. & Mondouri & 11 & 34 & 12 \\
10. & Pilicode & 28 & 6 & 62 \\
11. & Ratnagiri & 11 & 15 & 17 \\
12. & Veppankulam & 15 & & 30 \\
\hline
\end{tabular}

As most of the exotic types available at CPCRI have been assembled through germplasm exchange, data on the site of collection and source characters are not available. The recording is confined to appropriate entry in the Introduction Register giving details about the source, country of origin and local names. The local names are mostly derived based on fruit colour (green, yellow, orange etc.) bearing capacity (e.g. Ayiramkachi-1,000 nuts), size of nut (e.g. Kappadam-big nut), leaf characteristics etc. In some cases the name indicates the secondary source of introduction (Gujarat Zanzibar, Kulasekharam -Malayan Dwarf etc.) (Rao and Nayar, 1980).

\section{Documentation of Coconut Germplasm}

The IBPGR Consultation on Coconut Resotfrces held in January, 1978 at FAO Headquarters identified a minimum list of descriptors to be used in collecting the field data (IBPGR, 1978). The IBPGR descriptor list is mainly based on the descriptor made available by CPCRI and includes inforination on collection, evaluation, maintenance and occurrence of diseases.

\section{Evaluation}

\section{Nursery evaluation}

Descriptors used for evaluation at the nursery stage fall into two categories i.e. identifier and actual measurements. The local narne and accession number fall into first category. The number of days for germination, leaf length, leaf width, girth at collar and leaf showing first splitting fall into the second category. 


\section{Juvenile stage evaluation}

From the time the seedlings; arc transplanted into the field, the palm number has an important role as the identification is based on this number. As there is a time lag of 15-20 years between the initial introduction and final yield evaluation, it is absolutely necessary to maintain the individual identity within the accession for any numerical evaluation. The data on leaf production, leaf length, increment in girth and other growth parameters are recorded in the juvenile stage (before flowering 5-6 years old).

\section{Agronomic evaluation:}

Three registers are used for recording the data collected frorn the time the palm starts bearing. The Flowering Notes Register includes description on duration of male phase, duration of fernale phase, fernale flower distribution, length of peduncle, number of inflorescences produced and abortion of bunches. The Harvest Register (Yield Register) includes the mean number of fernale flowers per bunch, number of nuts harvested, and setting percentage. The Nut Characters Register includes data collected from nut analysis, fruit shape and nut shape (qualitative descriptors) and weight of fruits, nut and nut without water, meat (kernel) and copra (at 6\% moisture content) (IBPGR, 1978).

Evaluation of coconut germplasm is a long drawn process due to its long juvertile phase and also time taken for stabilisation of yield. For evaluating at the nursery stage, seedling characters such as the sprouting period of seed nuts, number of leaves, girth at collar and seedling height are generally used (Satyabalan and Mathew, 1976). Most of these characters have correlation with the adult palm bearing. An index was developed by Rao, and Mathew (1981) using, mean and CV of these characters for evaluation and characterisation of coconut germplasm at the nursery stage. Usually the performance of cultivar is evaluated against the local material only after stabilisation of yield which may take 15-20 years after planting. However, Rao, Satyabalan and Mathew (1978) found that it is possible to evaluate the germplasih accession at an early stage as the cumulative yield of first eight years had high correlation $\left(R^{2}=0.95\right)$ with the stabilised yield.

Among the exotic cultivars Fiji Tall, Fiji Longtongwan from Fiji Island, Philippines Ordinary Philippines Laguna from Philippines and Strait Settlement Green (SS Green) frorn Malaysia are superior to the local cultivar West Coast Tall,yielding over 30 per cent more nuts and 80-114 per cent more copra. Among the indigenous cultivars Kappadam, Andaman Ordinary and Lakshadweep Ordinary have higher yield potential than the local West Coast Tall. The performance of prornising cultivars of exotic and indigenous origin in given in Table 3.

Based on the overall performance in the four co-ordinating centres in Andhra Pradesh, Tamil Nadu, Karnataka, Maharashtra and at CPCRI Kasaragod, Lakshadweep Ordinary has been recommended for release under the name 'Chandra Kalpa'. This cultivar gave 33\% more yield in terms of nuts and $30 \%$ more copra yield at stabilised bearing period (Anonymous, 1985). Recently, Banawali Green Round with a mean number of 151 nuts and copra out turn of $22.8 \mathrm{~kg}$ has also been released.

The classification system based on fruit component analysis (Harries, 1978) and time taken for germination were adopted by Rao and Pillai (1982) to identify the degree of introgression in 40 accessions.

Rajagopal, Kasturibai and Voleti (1990) screened ten talls and six dwarf cultivars for the tolerance to drought using the sensitive parameters namely stomatal resistance (rs), leaf water potential (?) and epicuticular wax content (ECW). They observed that the coconut genotypes have varying response to the prevailing soil and atmospheric droughts during the surnmer months. In June, tall genotypes had relatively high rs, (?) and ECW as compared to the dwarfs. They concluded that it 
is possible to identify desirable drought tolerant characters in coconut genotypes under field conditions.

Studies on identifying coconut genotypes resistant/tolerant to root (wilt) disease were initiated by Varghese in 1934. Starting from 1961 CPCRI Regional Station Kayangulam has made considerable efforts to screen the available cultivars for their tolerance to root (Wilt) disease (Menon, Thommen and Sukumaran, 1981). Large scale field experiments were undertaken during 1972 in CPCRI Regional Station, Kayangulam and also in cultivators' garden in 63 villages of Alleppey, Quilon and Kottayam districts. Further screening trial involving 27 cultivars were laid out in cultivators'garden during 1982. Twenty-four exotic accessions collected from South Pacific Ocean Islands during 1981 are under evaluation at the CPCRI World Coconut Germplasm Centre, Sipighat in Andamans. Inter-se and selfed seed nuts arc being produced from these accessions and the first batch of seedlings from these source were planted in the 'hot spot' areas for screening for resistance/tolerance to root (wilt) disease. Thirty five West Coast Tall high yielding palms were identified based on intensive survey covering heavily diseased tracts ('hot spots') of Alleppey, Kottayam, Quilon and Pathanamthitta districts. These palms were confirmed to be disease free based on serological and physiological tests and these palms are being utilized in breeding programme to evolve the resistant/tolerant varieties in root (wilt) disease (Jacob and Rawther, 1991).

Table 3

PERFORMANCE OF PROMISING COCONUT CULTIVARS AT CPCRI, KASARAGOD

\begin{tabular}{|l|r|r|r|r|r|}
\hline \multirow{2}{*}{\multicolumn{1}{|c|}{ Cultivar }} & \multicolumn{2}{|c|}{$\begin{array}{c}\text { Mean Yield of } \\
\text { nuts/palm/year (17-20 } \\
\text { years) }\end{array}$} & \multicolumn{3}{c|}{ Copra yield } \\
\cline { 2 - 6 } & \multicolumn{1}{|c|}{ No. } & \% over WCT & *Nut (gm) & Palm/year (kg) & $\%$ over WCT \\
\hline Exotic & 106 & 55.9 & 179 & 19.0 & 86.3 \\
1. FIR TALL & 104 & 52.9 & 210 & 21.8 & 113.7 \\
2. FIJI LONGTONWAN & 108 & 58.8 & 198 & 21.4 & 109.8 \\
3. PHILIPPINES ORDINARY & 88 & 29.4 & 209 & 18.4 & 80.4 \\
4. PHILIPPINES LAGUNA & 108 & 58.8 & 189 & 20.4 & 100.0 \\
5. S.S. GREEN & & & & & \\
& & & & & \\
INDIGENOUS & 90 & 32.4 & 299 & 26.9 & 163.7 \\
1. KAPPADAM & 94 & 38.2 & 169 & 15.9 & 55.9 \\
2. ANDAMAN ORDINARY & 98 & 44.1 & 169 & 16.6 & 62.7 \\
3. LACCADIVE ORDINARY & 68 & - & 150 & 10.2 & \\
4. WEST COAST TALL & & & & & \\
\hline
\end{tabular}

* Source : PLACROSYM - V, 1982 pp. 112-124

\section{Future Strategy}

Screening work undertaken so far has indicated that tolerance to root (wilt) disease is not available among the germplasm accessions evaiuated so far. The fact that coconut belongs to a monotypic genus also limits the possibility of tapping gene pools from related species. As indicated earlier most of the exotic collections were assembled through exchange programmes and limited sample size collected from very few individual palms. In view of this, broadening the genetic base through collections from Melanasia, Micronesia and Indian Ocean Islands, which are known to have 
wide variability should receive top priority. Among the indigenous collections representative samples arc not available from Orissa, West Bengal and North Eastern regions.

It is necessary to have a sizeable population (minimum 10 paims per accession) of the collections maintained preferably at more than one location. Maintenance of a duplicate set would help in meaningful evaluation and also as a standby in case of a disease outbreak. The size of seednut imposes serious limitations in sample size and transportation involving exotic germplasm collection.

Embryo culture technique has been standardised in coconut and this can be effectively used for the future germplasm collection. However, further studies in embryo collection procedure, response in relation to age and storage periods, medium for maintaining the embryo during transit. and procedure involved in field planting are needed.

\section{REFERENCES}

ANONYMOUS, 1985. gn Proc. of the Seventh Workshop on All India Co-ordinated Coconut and Arecanut Improvement Project,Nov.,6-9,1985, Trivandrum. pp-160.

BECCARI, O. 1919. The Palms of the Philippines Islands. Philp. J. Sci. 14 : 295-362.

BRUMAN, H. J. 1945. Early coconut culture in Western Mexico, Hispanic American Historical Review, $25: 212-23$.

CHILD, R. 1974. Coconuts (2 ${ }^{\text {nd }}$ Edition). Longman Group Ltd. London, 335 pp.

CORNER, E. J. H. 1996. The Natural History of Palms. Weidenfeld and Nicolson, London, 393 pp.

de CANDOLLE, A. 1886. Origin of Cultivated Plants. Hafner Publishing Co., New York, 428 pp.

EDMONDSON, C. H. t941. Viability of coconut seed after floating in sea. Occasional papers of Bernice. P. Bishop Museum. Honolulu, Hawaii, 16 : 293-304

HARRIES, H.C. 1978. The evolution, dissernination and classification of Cocos nucifera L. Bot. Rev. $44: 265-319$

HILL, A. W. 1929. The original home and mode of dispersal of the coconut, Nature, 124 : 133-134, 151-1-53.

IBPGR, 1978. Coconut genetic resources. IBPGR report, AGPE/IBPGR/784. 24 pp. Secretariat, Rome.

JACOB, P. M. and RAWTHER, T. S. S. 1991. Varietal resistance, pp. 67-71. In : Coconut root (wilt) disease (Ed. Nair, M.K. et al.,) Central Plantation Crops Research Institute, Kasaragod. 92 pp.

KAUL, K. N. 1951. A palm fruit from Kapurdi (Jodhpur, Rajasthan desert) Cocos sahnii sp.,Curr. Sci., $20: 138$.

MARTIUS, C. F. P. 1850 (1823-50). Historia Naturalis Palmarum 3- Munich.

MENON, K.P.V. and PANDALAI, K.M. 1958. The Coconut Palm a monograph. Indian Central Coconut Committee Emakulam. pp. 384. 
MENON, K. S., THOMMEN, K. J. and SUKUMARAN, A. S. 1981. Varietal resistance studies. In Review of Research on Coconut root (wilt) disease. Central Plantation Crops Research Institute, Kayangulam. pp. 78-82 (Mimeographed).

PANDA, K. C. 1982. Coconut types of Orissa. Indian Coconut J. 13. 10-18.

PURSEGLOVE, J. W. 1972. Tropical Crops - Monocotyledons Longmans Group Ltd., London, 607 pp.

RAJAGOPAL, V., KASTURIBAI, K. V. and VOLETI, S. R. 1990. Screening of coconut genotypes for drought tolerance. Oleagineux, 45 (5) : 215-223.

RAMACHANDRAN, M., MURALIDHARAN, V. N. and BALASU- BRAMANIAN, K. 1977. A note on the new coconut variety Ayiramkachi, Indian Coconut J., 8: 4-6.

RAO, E. V. V. B. and KOSHY, P. K., 1982. Coconut Germplasm Collection in Pacific Ocean Islands. Deputation Report. (Mimeographed), pp. 47. Central Plantation Crops Research Institute, Kasaragod.

RAO, E. V. V. B. and MATHEW JACOB, 1981. An index for evaluation of coconut germplasm in the nursery. PLACROSYM IV: pp 200-205.

RAO, E. V. V. B. and NAYAR, N. M. 1980, Documentation of coconut germplasm. Workshop on Documentation of Genetic Resources, New Delhi. pp. 5 (Mimeographed).

RAO, E. V. V. B. and PILLAI, R. V. 1982. Characterization of coconut germplasm based on fruit component analysis. PLACROSYM V pp. 112-124.

RAO, E. V. V. B., SATYABALAN, K. and MATHEW JACOB. 1978. Evaluation of ten cultivars of coconut germplasm. Abstracts of papers presented at the All India High Level Symposium Researches in Plant Cytogenetic at Andhra University, Waltair, India, 9-12 Feb. 1978. pp. 9.

ROSENGARTEN, F. (Jr.) 1984. The Book of Edible Nuts.Walker and Company, New York, 384 pp.

SATYABALAN, K. and MATHEW JACOB. 1976. Identification of prepotent palms in West Coast Tall coconuts based on the early stages of growth of the progeny in the nursery. In Coconut Research and Development pp. 15-22. Wiley Eastern Limited New Delhi.

SWAMINATHAN, M. S. and NAMBIAR, M. C. 1961. Cytology and origin of the dwarf coconut palm. Nature $192: 8586$.

VARGHESE, M. K. 1934. Diseases of coconut palm. Supdt. Govt. Press, Trivandrum. pp. 105.

VAVILOV, N. I. 1851. The origin, variation, immunity and breeding of cultivated plants. Chronica Botanica, 13 : 1-366. 